ACTA THERIOLOGICA

Vol. 26, 1: 3-22, 1981

BISONIANA. LXXVII

\title{
Colour Phenotypes in Hybrids of the European Bison and Domestic Cattle
}

\author{
Małgorzata KRASIŃSKA \& Edward SUMIŃSKI
}

Krasińska M. \& Sumiński E., 1981: Colour phenotypes in hybrids of the European bison and domestic cattle. Acta theriol., 26, 1: 3-22 [With 4 Tables \& 5 Figs.]

Analysis was made of inheritance of coat colour in 203 hybrids of the European bison and domestic cattle of different breeds, obtained in the Mammals Research Institute, Polish Academy of Sciences at Białowieża, and the State Farm at Łekno. There were distinguished three basic coat colours: brown, black and red and two characters; self colour and white-spotting. The coat colour of hybrids depends on the coat colour of the parental forms, and on the homo- or heterozygotic state of these forms in respect of pairs of alleles responsible for the occurrence of coat colour pattern. It is assumed that the same dominating factor is responsible, in both European bison and in cattle, for the occurrence of the self colour. This factor may be allelomorphic with the gene responsible for occurrence of recessive white-spotting. Among the 89 hybrids obtained from the line of European bison $\times$ black and white lowland cattle, $88 \%$ were black, and $12 \%$ dark- or blackish brown. The possible causes of such colours occurring are discussed. The coat colour dilution in hybrids with Charolaise cattle blood may be connected with the presence of at least one dominant factor of the Charolaise breed $(D D)$. The authors were not able to carry out test crossbreeding, but limited themselves to defining hypothetic genotypes for the parental forms and hybrids in respect of loci $s, a, e$, and $d$.

[Mammals Research Institute PASc., 17-230 Białowieża (MK), and State Farm, Jeziory Wielkie, 63-020 Zaniemyśl (ES)]

\section{INTRODUCTION}

No attempts at analysis of inheritance of coat colour by hybrids European bison and domestic cattle have been found in the literature available, and what there is relating to hybrids of the American bison, is scanty (Deakin et al., 1935, 1941). A fundamental difficulty was encountered in the lack of data on genotypes of coat colour in both the European and American bisons. In respect of the American bison's colour Serle (1968) writes in his monograph only that sthe wild type seems to be non agouti brown «. More attention has been given to domestic catle in this respect. Genetic bases of colour inheritance in domestic catle were supplied by the papers by Staffe (1925), Ibsen (1933), Bogart 
\& Ibsen (1937). The theories put forward by these authors have been tested by cross-breeding differently coloured breeds of cattle, which has shown that the basic colours in cattle are inherited in accordance with the proposed genotypes, but has not provided an explanation for the formation of different shades of coat colour in hybrids (WietheKöprich. 1952; Kleisch-Horst, 1960). Lauvergne (1966) has attempted to interpret the problem of coat colour in cattle in accordance with the genetic situation in other mammals but, as Searle (1968) emphasized, far more breeding experiments are required before either confirmation or refutation of these authors' ideas can be found.

The purpose of the present study was to document coat colour phenotypes in hybrids of the European bison and domestic cattle currently obtained in Poland, and to attempt to investigate their inheritance. We anticipated that the results obtained would be of doubtful assistance in explaining at least part of the present points in inheritance of coat colour in domestic cattle.

\section{MATERIAL AND METHODS}

The material consisted of hybrids of the European bison land domestic cattle of both sexes obtained in the Mammals Research Institute of the Polish, Academy uf Sciences at Białowieża, and the state Farm Jeziory (Wielkie at Eękno (Table 1). Białowieża generation $F_{1}$ hybrids were obtained by crossing European bison of both sexes with the red Polish breed $(r p)$ and black-white lowland breed (bwl) of domestic cattle. Backcross generations were obtained by mating hybrid cows of different generations with bwl breed bulls (Krasinska, 1967, 1971, 1979). Male hybrids of all generations were sterile. The bwl cows covered at Bialowieża/were of unknown, parentage, unlike the $r p$ cattle used there. A At Łękno $F_{1}$ hybrids were obtained by cross-breeding European bison with cows of the black and white lowland, red Polish, red Polish-Simmentaler and black and white lowland $\times$ Charolaise $(b w l \times c h)$ (Malecka \& Sumiński, 1976). The cattle were of either known (sometimes only on the paternal side) or unknown origin. $\mathrm{B}_{1}$ hybrids (3/4 European bison $1 / 4$ cattle) were obtained at Łękno by crossing European bison with $F_{1}$ cows after mother bwl or bwl $\times \bumpeq h$ mothers (Table 1 ).

Despite the relatively large number of studies on the subject of coat colour in cattle, no data were encounitered on coat colour genotypes of the Polish breeds we used for crossing with European bison. On the principle of analogy, we assumed in our discussions certain general premises based on data for other European breeds of cattle. It is considered that self colour in cattle is connected with the presence of the dominant $S$ gene, which may be allelomorphic with recessive white-spotting $s$ or $s p, s_{1}, s_{2}$ (Staffe, 1925; Ibsen, 1933; Shrode \& Lush, 1947; Danneel, 1965; Johanson et al., 1966; Searle, 1968).

In relation to the black colour of European breeds of cattle Lauvergne (1966) suggests that it may be connected with the coaction of genes $a^{s}$ and $E^{+}$, as opposed to the red colour, where the recessive allele $e^{r}$ operates. The light (yellowishwhite) coat colour in the Charolaise breed of cattle may be, according to Lauvergne's working hypothesis (1966), connected with the action of the dominant gene in locus $D$, with co-action of the additional recessive factor $c c h$. Proof of 
the existence of this dominan't factor may be the dilution of coat colour in hybrids of this breed with other red and black coloured breeds, as described by Berge (1965). On the other hand genes of loci $A$ and $C$ may participate in such cases (Searle, 1968). It was assumed, that the brown colour of the European bison is connected with a dominant modifier, which affects on recessive extension of phaeomelanin to darken the coat and make it look brown. On the basis of the study by Lauvergne (1966), the following, hypothetical genotypes of coat colour of the parental forms and of European bison $\times$ cattle hybrids in loci $a, s, e, d$ and specific for wisent dominant modifier $M$ have been suggested:

Table 1

Study material consisting of hybrids of European bison and domestic cattle.

\begin{tabular}{|c|c|c|c|c|c|}
\hline \multirow{2}{*}{\multicolumn{2}{|c|}{ Type of mating }} & \multicolumn{4}{|c|}{ Hybrids obtained (n) } \\
\hline & & Generation & Białowieża & Łękno & Total \\
\hline$o^{x} w$ & $\times q b w l$ & $\mathrm{~F}_{1}$ & 5 & 83 & 88 \\
\hline$o^{x} b w l$ & $\times q w$ & $F_{1}$ & 1 & - & 1 \\
\hline$\sigma^{x} w$ & $\times \quad q r p^{1}$ & $F_{1}$ & 2 & 5 & 7 \\
\hline$\sigma^{\pi} r p$ & $\times q w$ & $\mathrm{~F}_{1}$ & 3 & - & 3 \\
\hline$\sigma^{x} w$ & $\times \quad$ \& (bwl $\times$ ch $)$ & $\mathrm{F}_{1}$ & - & 18 & 18 \\
\hline Total I & & & 11 & 106 & 117 \\
\hline$\sigma^{x} w$ & $\times \circ \mathrm{F}_{1}$ & $\mathrm{~B}_{1}$ & - & 27 & 27 \\
\hline$\sigma^{\top} b w l$ & $\times \quad \mathrm{F}_{1}$ & $\mathrm{~B}_{1}$ & 28 & - & 28 \\
\hline$o^{*} b w l$ & $\times \quad \mathrm{B}_{1}$ & $\mathrm{~B}_{2}$ & 24 & - & 24 \\
\hline$\sigma^{x} b w l$ & 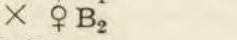 & $\mathrm{B}_{3}$ & 7 & - & 7 \\
\hline All mati & & $\mathrm{F}_{1}-\mathrm{B}_{3}$ & 70 & 133 & 203 \\
\hline
\end{tabular}

Abbreviations: $w$ - European bison or wisent, bwl - black and white lowland cattle, rp - red Polish cattle, ch - Charolaise cattle, $F_{1}-$ hybrids $1 / 2$ wisent $1 / 2$ cattle, $B_{1}-$ hybrids $1 / 4$ wisent $3 / 4$ cattle or $3 / 4$ wisent $1 / 4$ cattle, $B_{2}$ hybrids $1 / 8$ wisent $7 / 8$ cattle, $B_{3}$ - hybrids $1 / 16$ wisent $15 / 16$ cattle, ${ }^{1}$ one cow red Polish $\times$ simmentaler.

European bison - $a^{s} a s$ SS $e^{r} M e^{r} M d d-$ brown

bwl breed of cattle - asas SS EE dd (the heterozygotic forms of this breed may have differences in respect of loci $s e-S s, E e^{r}$ ) - black and white (spotted)

$r p$ breed of cattle - as as $S S e^{r} e^{r} d d$ - red

Charolaise - asas $S S$ er $^{r} D D$ - yellowish-white

hybrid cattle of bwlXch breeds - asass $s E e^{r} D d$ - whitish-grey

Since material which was to some extent unique was available, endeavour was made fully to document the matings arranged and the patterns of coat colour in the hybrids obtained from them. The occurrence of basic coats such as brown (without analyzing shade), black or red was traced in different combinations of hybrids and different generations, reviewing separately the occurrence of the characteristic of self colour and white spotting and minior white-spotting. The final question to which attention was given was dilution of coat colour in hybridrs obtained form bwl $\times$ ch cattle.

The material discussed was grouped in three lines to which hybrids from the following initial groups were allocated:

Line I $\sigma^{\pi}$ European bison $\times o$ cattle of black/white lowland and Charolaise breed

Line II $-\sigma^{x}$ ㅇ European bison $x$ 우 $\sigma^{x}$ red Polish breed 
Line III $-\sigma^{x}$ ㅇ European bison $x$ ㅇ $\sigma^{x}$ black/white lowland breed

In order to determine the possible combination's of coat colour in hybrids use was made of the genetic chequeredboard (Punnett's square), taking the hypothetical premises given above from coat colour genetics of cattle as a basis.

\section{RESULTS}

\section{Inheritance of Self Colour}

Two of the initial forms used in the experiment fully represented self colour - European bison and $r p$ breed cattle. Only one cow of this breed, obtained from Łękno, had white spots. Bwl Xch cows were self coloured and bwl breed of cattle spotted.

If it is assumed that self colour is a dominant characteristic in both domestic cattle and the European bison, in generation $F_{1}$ self colour hybrids only should be obtained (both the homo- and heterozygotic forms in respect of this characteristic). All the $F_{1}$ hybrids obtained were selfcoloured (117 individuals), two of them having a larger amount of white spots (after $b w l$ ). The majority of $F_{1}$ hybrids obtained from $b w l$ breed cattle had smaller or larger white spots (minor white-spotting) situated on the end of the tail, hocks, fore head and in one case on the belly (Table 2).

In hybrids of backcross generations towards bwl cattle, with increasing participation of cattle blood of this breed the number of spotted individuals increase, in accordance with the rules of heredity (Table 2).

\section{Inheritance of Dilution of Coat Colour Originating from the Charolaise Breed of Cattle}

Hybrid cows of bwl $\times$ ch origin (heterozygotic forms in respect of the dominant dilution factor) had light-coloured coats (whitish-grey). If such lightening of coat colour is a dominant character, then it should appear in $50 \%$ of the $\mathrm{F}_{1}$ hybrids obtained by crossing these cows with cattle (Line I). In accordance with our premises, we obtained $9 \mathrm{~F}_{1}$ hybrids with dark coats (brown, dark brown and black) and 9 light coloured individuals (Table 3, Appendix I Fig. 1). In backcross hybrids towards European bison, obtained from $F_{1}$ dark-coloured cows, this phenotype should not appear at all, and this was in fact the case. It might, however, have occurred in $50 \%$ of cases in progeny of lightcoloured $F_{1}$ cows. In this last combination four light-coloured individuals were obtained (Table 3, Appendix I Fig. 1). 
Table 2

Inheritance of self colour in European bison and domestic cattle hybrids in line I-III.

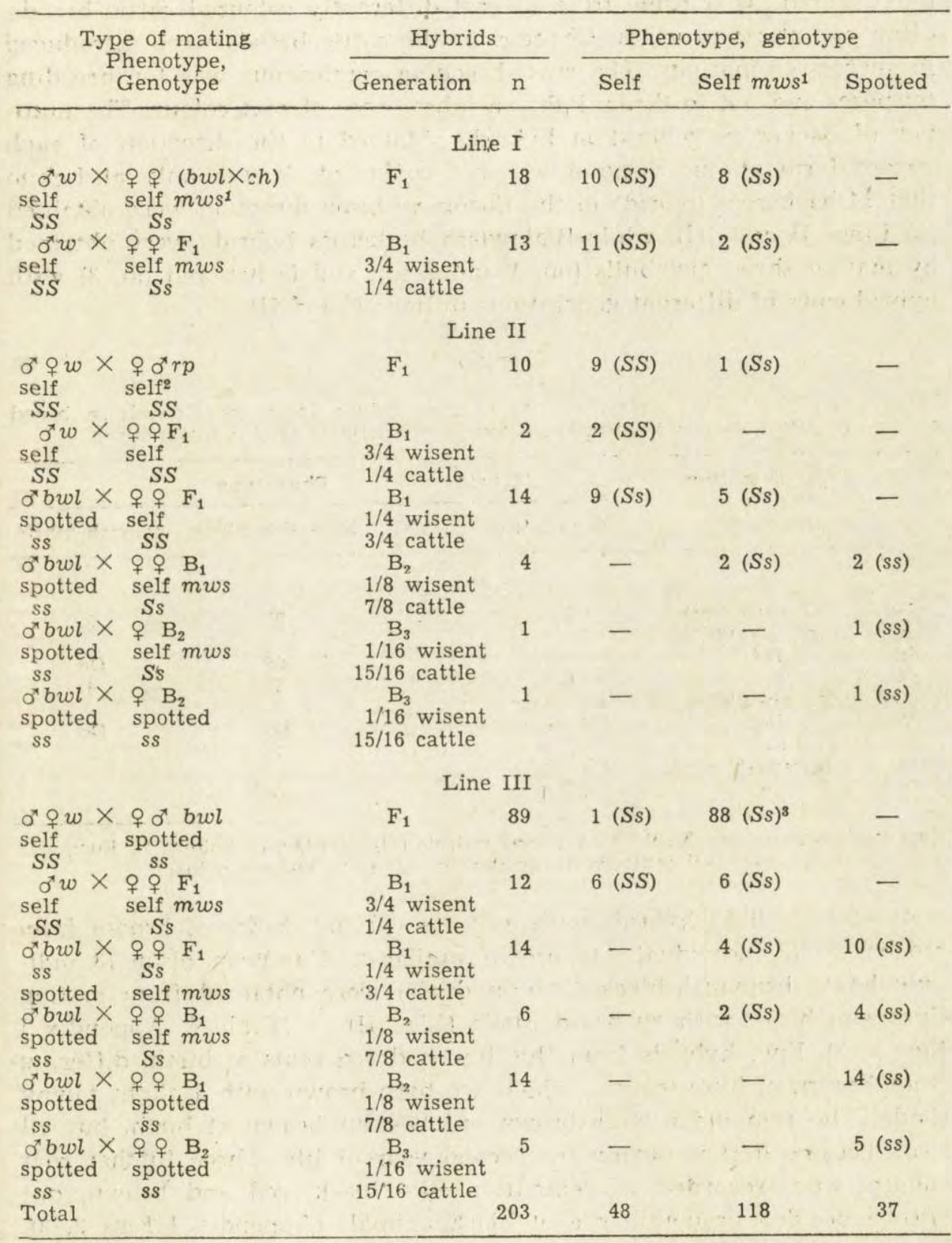

For explanations of symbols see table $1 .{ }^{1}$ Self mws means self with minor white spotting, 2 One individual with minor white spotting; ${ }^{3}$ Two individuals with large white spots. 


\section{Inheritance of Basic Coat Colours of the Parental Forms}

It was difficult to trace inheritance of coat colour in the material at our disposal, as it came from several differently coloured cattle breeds, often of unknown origin. Changes in the cattle breeds were introduced in successive matings. The cross-breeding carried out was for breeding purposes and not to throw light on inheritance of coat colour. The number of backcross generation hybrids obtained in the direction of each parent form at our disposal was not sufficient. It was only at Łękno that 14 backcross hybrids in the European bison direction were obtained (in Lines II and III), while Białowieża backcross hybrids were obtained by mating three bwl bulls (no. 1 and 2 son and father and no. 3) with hybrid cows of different generations in lines II and III.

\section{Table 3}

Inheritance of dilution characteristics of coat colour from the Chanolaise breed of cattle, in line I European bison $\sigma^{\pi} \times$ cattle $q$ (bwl $\times$ Charolaise).

\begin{tabular}{|c|c|c|c|c|c|}
\hline & \multirow{2}{*}{$\begin{array}{c}\text { Type of mating } \\
\text { Phenotype } \\
\text { Genotype }\end{array}$} & \multicolumn{2}{|c|}{ Hybrids } & \multicolumn{2}{|l|}{ Phenotype } \\
\hline & & Generation & $\mathrm{n}$ & brownish black & greyish-white \\
\hline \multicolumn{6}{|c|}{ Line I } \\
\hline \multirow{6}{*}{$\begin{array}{c}\sigma^{x} w \times \\
\text { brown } \\
d d \\
\sigma^{\top} w \times \\
\text { brown } \\
d d \\
\sigma^{\top} w \times \\
\text { brown } \\
d d\end{array}$} & $\times$ 우 $(b w l \times c h)$ & $F_{1}$ & 18 & $9^{1}$ & 9 \\
\hline & $\begin{array}{l}\mathrm{Dd} \\
\times\end{array}$ & & & $d d$ & $D d$ \\
\hline & ${ }_{1}^{X} \underset{\text { greish-white }}{q} \underset{F_{1}}{F_{1}}$ & $\begin{array}{c}\mathrm{B}_{1} \\
3 / 4 \text { wisent }\end{array}$ & 6 & $2^{2}$ & 4 \\
\hline & $\begin{array}{r}D d \\
\times\end{array}$ & $1 / 4$ cattle & & $d d$ & $D d$ \\
\hline & brownish black & $\begin{array}{l}{ }_{3} \\
3 / 4 \text { wisent }\end{array}$ & 7 & & - \\
\hline & $d d$ & $1 / 4$ cattle & & $d d$ & \\
\hline
\end{tabular}

For explanations see Table 1. ${ }^{1}$ Three individuals similar in colour to European bison; ${ }^{2}$ All individuals similar in colour to European bison.

A total of $10 \mathrm{~F}_{1}$ hybrids with coats in various shades of brown from red-brown ( 2 individuals) to brown similar to European bison ( 3 individuals) to brownish-black ( 5 individuals) were obtained from mating European bison with $r p$ breed cattle (Line II) - (Table 4, Appendix I Figs 2, 3). Five hybrids from this line had red coats at birth, differing from European bison calves, which are born brown with a slight tawny shade. The remainder were brown or chestnut brown at birth, but all coats became darker during the second year of life. Three further coat colours were recorded in generation $\mathrm{B}_{1}$ - black, red and brown, but with a decided predominance of black animals (Appendix I Figs 2, 3). In generation $B_{2}$ there were only red or black individuals, and in generation $\mathrm{B}_{3}$ black only (Table 4, Appendix I Figs 2,3). 
Table 4

Inheritance of basis coat colours in line II and III hybrids.

\begin{tabular}{|c|c|c|c|c|c|c|}
\hline \multirow{2}{*}{\multicolumn{2}{|c|}{$\begin{array}{c}\text { Type of mating } \\
\text { Phenotype, } \\
\text { Genotype }\end{array}$}} & \multicolumn{2}{|l|}{ Hybrids } & \multicolumn{3}{|c|}{ Phenotype, genotype } \\
\hline & & Generation & $\mathrm{n}$ & Brown ${ }^{1}$ & Black $^{2}$ & Red $^{s}$ \\
\hline & & \multicolumn{2}{|c|}{ Line II } & & \multirow{4}{*}{ - } & \multirow{4}{*}{ - } \\
\hline $\begin{array}{l}\sigma^{x} \text { + } w \times \\
\text { brown: }\end{array}$ & $\begin{array}{l}\text { qox } r p \\
\text { red }\end{array}$ & $\mathrm{F}_{1}$ & 10 & 10 & & \\
\hline$a^{s} a s e^{r} M e^{r} M$ & $a^{s} a^{s} e^{r}{ }^{2}$ & & & $a^{s} a^{s} e^{r} e^{r} M$ & & \\
\hline $\begin{array}{c}\sigma^{\pi} w \times \\
\text { brown } \\
a^{s} a^{s} e^{r} M e^{r} M\end{array}$ & $\begin{array}{l}2 \underset{q}{q} \mathrm{~F}_{1} \\
\text { brown } \\
a^{s} a^{s} e^{r} e^{r} M\end{array}$ & $\begin{array}{l}\mathrm{B}_{1} \\
3 / 4 \text { wisent } \\
1 / 4 \text { cattle }\end{array}$ & 2 & $a^{s} a^{s} e^{2^{5}} \mathrm{Me}^{r} M$ & & \\
\hline no. $\begin{array}{l}\sigma^{\top} \sigma^{x} b w l \times \\
a^{s} a^{s} E e^{r}\end{array}$ & $\begin{array}{l}2 \text { 우 } \mathrm{F}_{1} \\
\text { brown } \\
a^{s} a^{s} e^{r} e^{r} M\end{array}$ & $\begin{array}{l}B_{1} \\
1 / 4 \text { wisent } \\
3 / 4 \text { cattle }\end{array}$ & 9 & $a^{s} a^{s} e^{r} e^{r} M$ & $\begin{array}{c}7^{4} \\
a^{s} a^{s} \mathrm{Ee}^{r} \\
\left(E e^{r} M\right)\end{array}$ & $\begin{array}{c}1 \\
a^{s} a^{3} e^{r} e^{r}\end{array}$ \\
\hline $\begin{array}{l}\sigma^{\top} b w l \times \\
\text { no. } 1 \text { black } \\
a^{s} a^{s} E e^{r}\end{array}$ & 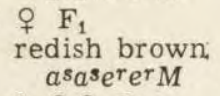 & $\begin{array}{l}\mathrm{B}_{1} \\
1 / 4 \text { wisent } \\
3 / 4 \text { cattle }\end{array}$ & 5 & $a^{s} a^{s} e^{r} e^{r} M$ & $\begin{array}{c}1 \\
a^{s} a^{s} E e^{r}\end{array}$ & $\begin{array}{c}3 \\
a^{s} a^{s} e^{r} e^{r}\end{array}$ \\
\hline no. $\begin{array}{l}\sigma^{\top} \sigma^{x} b w l \times \\
a^{s} a^{s} E e^{r}\end{array}$ & $\begin{array}{l}2 q \circ \mathrm{B}_{1} \\
\text { red } \\
a^{s} a^{s} e^{r} e^{r}\end{array}$ & $\begin{array}{l}\mathrm{B}_{2} \\
1 / 8 \text { wisent } \\
7 / 8 \text { cattle }\end{array}$ & 4 & - & $\begin{array}{c}1 \\
a^{s} a^{s} E e^{r}\end{array}$ & $\begin{array}{c}3 \\
a^{s} a^{s} e^{r} e^{r}\end{array}$ \\
\hline no. $\begin{array}{l}\sigma^{\top} \sigma^{\top} b w l \times \\
a^{s} a^{s} E e^{r}\end{array}$ & $\begin{array}{l}2 q_{1}^{\circ} \mathrm{B}_{2} \\
\text { red }^{8} \\
a^{s} a^{s} e^{r e r}\end{array}$ & $\begin{array}{c}\mathrm{B}_{3} \\
1 / 16 \text { wisent } \\
15 / 16 \text { cattle }\end{array}$ & 2 & - & $a^{2} a^{5} E e^{r}$ & - \\
\hline & & Line & III & & & \\
\hline $\begin{array}{c}\sigma^{x}+w \times \\
\text { brown } \\
a^{s} a^{s} e^{r} M e^{r} M\end{array}$ & $\begin{array}{l}\text { ○ } \sigma^{x} \text { bwl } \\
\text { black } \\
a^{s} a^{s} E E\left(E e^{r}\right)\end{array}$ & $F_{1}$ & 89 & $\begin{array}{c}11 \\
a^{s} a s e^{r} e^{r} M \\
\left(\text { Eer }^{r} M\right)\end{array}$ & $\begin{array}{c}78 \\
a^{s} a^{3} E e^{r} M\end{array}$ & - \\
\hline brown & $\underset{\text { black }^{1}}{4 \underset{+}{q}} F_{1}$ & ${ }_{3 / 4} \mathrm{~B}_{1}$ wisent & 6 & $a^{s} a^{s} e^{r} \operatorname{Mer}^{5} M$ & $a^{s} a^{s} \frac{1}{E e^{r} M}$ & - \\
\hline $\begin{array}{c}a^{s} a^{s} e^{r} M e^{r} M \\
\sigma^{x} w \times\end{array}$ & $\begin{array}{ll} & a^{s} a^{s} e^{r} e^{r} M \\
5 & \circ \\
\end{array}$ & $\begin{array}{c}1 / 4 \text { cattle } \\
\mathrm{B}_{1}\end{array}$ & 6 & $6^{8}$ & & \\
\hline $\begin{array}{c}\text { brown } \\
a^{s} a^{s} e^{r} M e^{r} M\end{array}$ & $\begin{array}{l}\text { brown } \\
a^{s} a^{s} e^{r} e^{r} M\end{array}$ & $\begin{array}{l}3 / 4 \text { wisent } \\
1 / 4 \text { cattle }\end{array}$ & 0 & $\begin{array}{l}a^{s} a^{s} e^{r} e^{r} M \\
\left(e^{r} M e^{r} M\right)\end{array}$ & - & - \\
\hline $\begin{array}{l}\sigma^{x} \sigma^{x} b w l \times \\
\text { no. } 1,2, \\
\text { black } \\
a^{s} a^{s} E e^{r}\end{array}$ & $\begin{array}{l}\text { o } F_{1} \\
\text { brown } \\
\quad a^{s} a^{s} e^{r} e^{r} M\end{array}$ & $\begin{array}{l}\mathrm{B}_{1} \\
1 / 4 \text { wisent } \\
3 / 4 \text { cattle }\end{array}$ & 2 & - & $a^{s} a^{3} \stackrel{2}{E e^{r} M}$ & - \\
\hline $\begin{array}{c}\sigma^{\pi} \sigma^{\top} b w i \times \\
\text { no. } 1-3 \text { black } \\
a^{s} a^{s} E e^{r}, E E\end{array}$ & $\begin{array}{l}2 q q \mathrm{~F}_{1} \\
\text { black } \\
a^{s} a^{s} E e^{r} M\end{array}$ & $\begin{array}{l}\mathrm{B}_{1} \\
1 / 4 \text { wisent } \\
3 / 4 \text { cattle }\end{array}$ & 12 & $\stackrel{4}{a^{s} a^{s} e^{r} e^{r}}$ & $\begin{array}{c}8 \\
a^{s} a^{s} E E \\
E e^{r}\end{array}$ & - \\
\hline $\begin{array}{c}\sigma^{\top} b w l \times \\
\text { black } \\
\text { no. } 2,3 \\
a^{s} a^{s} E e^{r}, E E\end{array}$ & $\begin{array}{l}5 \text { 우 } \mathrm{B}_{1} \\
\text { black } \\
a^{s} a^{s} E E \text { (Eer?) }\end{array}$ & $\begin{array}{l}\mathrm{B}_{2} \\
1 / 8 \text { wisent } \\
7 / 8 \text { cattle }\end{array}$ & 15 & - & $a^{s} a^{3} E E\left(E e^{r}\right)$ & $\stackrel{1}{a^{s} a^{s} e^{r} e^{r}}$ \\
\hline $\begin{array}{c}\sigma^{\top} \sigma^{\top} b w l \times \\
\text { no. } 1-3 \text { blak } \\
a^{3} a^{3} E e^{r}, E E\end{array}$ & $\begin{array}{l}2 \text { 우 } q \mathrm{~B}_{1} \\
\text { brown } \\
a^{3} a^{3} e^{r} e^{r} M\end{array}$ & $\begin{array}{l}\mathrm{B}_{2} \\
1 / 8 \text { wisent } \\
7 / 8 \text { cattle }\end{array}$ & 5 & - & $\begin{array}{c}3 \\
a^{s} a^{s} \mathrm{Eer}\end{array}$ & $\stackrel{2}{a^{s} a^{s} e^{r} e^{r}}$ \\
\hline $\begin{array}{c}\text { no. } 3 \text { black } \\
a^{s} a^{s} E E\end{array}$ & $\begin{array}{l}2 \text { 우 } \mathrm{B}_{2} \\
\text { black } \\
\quad a^{s} a^{s} E E\end{array}$ & $\begin{array}{c}\mathrm{B}_{3} \\
1 / 16 \text { wisent } \\
15 / 16 \text { cattle }\end{array}$ & 3. & - & $\begin{array}{c}3 \\
a^{3} a^{5} E E\end{array}$ & - \\
\hline $\begin{array}{l}\text { ơbwl } \times \\
\text { no. } 3 \text { black } \\
a^{s} a^{s} E E\end{array}$ & $\begin{array}{l}\stackrel{\mathrm{B}_{2}}{+} \\
\text { red }^{3} \\
\qquad \mathrm{a}^{\mathrm{s}} \mathrm{a}^{\mathrm{s}} \mathrm{e}^{\mathrm{r}} \mathrm{er}^{\mathrm{r}}\end{array}$ & $\begin{array}{c}\mathrm{B}_{3} \\
1 / 16 \text { wisent } \\
15 / 16 \text { cattle }\end{array}$ & 2 & - & $\begin{array}{c}2 \\
a^{s} a^{s} E e^{r}\end{array}$ & - \\
\hline
\end{tabular}

Explanations: 1 Various shades from tawny-brown to black-brown; 2 Including black-white spotted; ${ }^{3}$ Including red-white spotted; 1 Three individuals of this group with red coat at birth; 5 Colour similar to European bison; - Four individuals similar in colour to European bison; ${ }^{7}$ Including one spotted calf. All individuals of bwl breed of cattle - spotted. Abbreviations see Table 1 . 
When crossing European bison with bwl breed cattle (Line III) 89 $\mathrm{F}_{1}$ hybrids were obtained, of which 78 were black, a lighter shade of the woolly hair occurring in part of the animals. Eleven hybrids of this line had dark-brown coats. Of these, four hybrids had red or reddish-chestnut coats at birth. Of the two cows which produced more then one calf from mating with European bison, one produced two black calves, and the second a black and dark brown calf. When $F_{1}$ cows of this line were mated with European bison, as anticipated the number of calves with brown coats similar to that of the European bison increased (9 out of the 12 obtained - Table 4, Appendix I, Figs 4, 5).

In backcross generations towards domestic cattle in this line the number of black animals increased as anticipated. In generation $B_{1}$ (1/4 European bison, $3 / 4$ domestic cattle) the number of black individuals in comparison with brown was $10: 4$, while there were no brown animals in generation $B_{2}$, but the number of black individuals rose to 17 . Three animals with red coats appeared in this generation. As anticipated generation $B_{3}$ was entirely black (Table 4, Appendix I Figs 4, 5).

\section{DISCUSSION}

Hybrids of European bison and domestic cattle obtained in different experiments were characterized by variety of coat colour. The most important factor affecting this was the coat colour of the parental forms, different in the case of different cattle breeds crossed with European bison. There is unfortunately a lack of exact information is earlier studies on both the coat colour of domestic cattle crossed with the European bison and of hybrids. Two of the oldest $F_{1}$ hybrids described, obtained from mating European bison with domestic cattle of the szwyc breed, by L. Walicki (Karcov, 1903) differed as to coat colour. The bull was similar in colour to bison (Müller, 1852; Karcov, 1.903), while the cow's coat was described as dark chestnut, with a white line along the back from the shoulder blade to tail, and a white belly. No description is given of the colour of $1 / 4$ European bison $3 / 4$ domestic cattle hybrids obtained by Walicki, who limited himself to standing that they were similar in colour to cattle (Karcov, 1903).

Other $F_{1}$ hybrids obtained at the end of the 19th and beginning of the 20th century in Askania Nova, by crossing European bison with the grey Steppe breed of cattle, were light red at birth, darkening as they grew older and reaching a colour intermediate between that of European bison and cattle (Iwanow \& Philiptschenko, 1916). Askanian triple hybrids, however, female cattle-bison $\times$ European bison, and thus with a predominance of Bison genus blood, were brown-coloured like European bison or slightly darker. The hybrids $3 / 4$ European bison 1/4 
domestic cattle from this breeding centre were similar in colour to European bison, except that one animal was lighter and a second darker, than European bison (Iwanow \& Philiptschenko, 1916). $\mathrm{F}_{1}$ hybrids obtained at Askania Nova during the thirties from mating American bison males with grey steppe cows and simmentaler hybrids were light brown at birth, became darker later with a light-coloured surround to the muzzle (Zuravok, 1935).

Further hybrids obtained in the Plock Zoo from crossing European bison with a domestic cow (watussi $\times$ bwl) had brown colour and minor white spotting (Taworski \& Wolinski, 1960), and were thus similar to some of the hybrids from our line III.

When analyzing the colour of hybrids related to the European bison, American bison and domestic cattle (Deakin et al., 1935), the heredity formulae proposed for domestic cattle by Ibsen (1935) were taken as 'a basis. This analysis was very difficult on account of the enormous variety of coat colour in hybrids originating from different breeds of domestic cattle crossed with American bison. The picture was even further complicated by the occurrence of the brindled pattern in the majority of hybrids. The method accepted, however, enabled the authors to interpret the formation of different coat colours in hybrids, and even the brindled pattern. Deakin et al. $(1935,1941)$ realized that their premises were hypothetical and that other factors, résponsible for modification of coat colour in hybrids, might operate in American bison from those in domestie cattle. The analysis made by these authors justifies the conclusion that the American bison possesses self colouring caused by a similar dominant factor to that in domestio cattle $(S)$. Hybrids originating from Hereford cattle always had white heads, which is connected with the presence of the dominant factor responsible for forming this characteristic in cattle $\left(\mathrm{SH}^{\mathrm{H}}\right)$ (Deakin et al., 1935).

A factor equally as important as the coat colour of initial forms, and affecting the formation of the colour phenotype in hybrids, is the state of homo- or heterozygosity of the parent forms in respect of pairs of alleles responsible for the occurrence of their given pattern of coat 'colour. The lack of information on the origin of a' large part of the cattle crossed with European bison made it impossible to accept assumptions as to the homozygotic character of factors ersponsible for the breed colour characteristics of all the mated individuals. There was certainty only in respect of all European bison. The appearance of the red coat in generation $B_{2}$ of line III hybrids may point to the heterozygotic character in relation to the gene in locus extension in the two bwl bulls no. 1 and 2 (father and son), and matings in a different line with the same males confirms this assumption. 
The analysis we made justifies the conclusion that both in domestic cattle and in European bison a similar dominant factor $(S)$ is responsible for the occurrence of the self colour characteristic. This factor may be allelomorphic with the gene responsible for the occurrence of recessize white spotting, although we consider that the factor responsible for white spotting is not fully recessive, since all self colour $F_{1}$ hybrids from bwl cattle had minor white spotting on the forehead, hocks and tail, and two individuals even had a large amount of white patches. In domestic cattle also, according to several authors, this factor is not fully recessive (Wiethe-Körprich, 1952; Danneel, 1965; Johanson et al., 1966; Searle, 1968).

In $F_{1}$ hybrids from bwl cattle the black colour deriving from cattle is a dominant characteristic in relation to the brown bison colour, since $88 \%$ of the hybrids in this line had black coats. The occurrence of brownish-black colour in $12 \%$ of hybrids may be connected with heterozygosity of part of the bwl breed of cattle used for crossbreeding, in respect of the gene in locus extension $\left(E e^{T}\right)$, and then hybrids could have genotype $e^{r} e^{r} M$. Another explanation of the occurrence of such colour in some $F_{1}$ hybrids leads to the conclusion that in hybrids in certain cases the genes may exert a suppressing effect of the bison's dominant modifier on gen in locus extension. It can be expressed for unknown reasons in such a small group of hybrids.

The question of coat colour in $F_{1}$ hybrids from mating European bison with cattle of the $r p$ breed is different. In this case we can observe different shades of brown, from reddish-brown through brown similar to European bison up to brownish-black. This fact would appear to be the result of co-action in the hybrids' organism of genes responsible for the brown coat colour of European bison and red domestic cattle, of which at least part may occupy identical loci (ererM). The brown colour of all $\mathrm{F}_{1}$ hybrids in this line, as well as the colour analysis of the backcross generations toward the bison confirms our assumptions about a possibility of existence in the European bison the dominant modifier affecting on recessive extension of phaeomelanin to darken the coat and make it look brown. In hybrids of backckross generations towards domestic cattle the black colour is a character dominant in relation to red, with a state of homozygosity in respect of the characteristics responsible for the black colour in one of the parental forms. The fact that dilution of colour was found in hybrids with Charolaise cattle blood may form proof that in this breed the light colour may be the result of action of inter alia the dominant factor. Thus our observations may provide support for hypotheses on this subject (Lauvergne, 1966; Searle, 1968). 
As we were unable to carry out test crossbreedings it was impossible to determine the genotypes of coat colour in parental forms and also in hybrids. Use was made of hypothetical assumptions, based on data on cattle genetics, which enabled us to account for the basic coat colours obtained in hybrids. This justifies the conclusion that Lauvergne's premises (1966) for European breeds of cattle are probable correct. We assume that our results will contribute to progress in studies in this field on domestic cattle.

Acknowledgements: The authors' thanks are due to Professor A. G. Searle (Harwell), Professor Maria J. Radomska (Warsaw) and Professor Zbigniew Staliński (Kraków) for their valuable comments during work on the typescript.

\section{REFERENCES}

1. Berge S., 1965: Haarfarbe und Haarzeichnung bei Kreuzungen von gelbweissen Charollaise mit roten und schwarzen Kühen. Z. f. Tierzucht Zuchtbiol., 81: $46-54$.

2. Bogart R. \& Ibsen H. L., 1937: Relation of pigmentation to colour inheritance. J. Genetics, 35: 31-59.

3. Danneel R., 1965: Die Scheckung der Schwarzbunten Niederungsrinder $\mathbf{Z}$. Naturf., 20: 375-378.

4. Deakin A., Muir G. W. \& Smith A. G., 1935: Hybridization' of domestic cattle, bison, yak. Report of the Wainwright experiment. Publ. Dep. Agric. Can., 479: $1-30$.

5. Deakin A., Muir G. W., Smith A. G. \& Lellan A. S., 1941: Hybridisation of domestic eattle and buffalo (Bison americanus). Progress report off the Wainwright experiment 1935-41. Techn. Biul., 2: $1-27$

6. Ibsen H. L., 1933: Cattle inheritance. J. Genetics, 18: 439-480.

7. Iwanow E. \& Philiptschenko J., 1916: Beschreibung von Hybriden zwischen Bison, Wisent und Hausrind in Tierpark Askania Nova des Herrn F. E. Falz-Fein. Ztschr. f. in'dik. Abst. und Vererb. Lehre., 16, 1/2: 1-48.

8. Johanson I., Rendel J. \& Gravet H. O., 1966: Haustiergenetik und Tierzüchtung. Verlag Paul Parey: 1-358. Hamburg und Berlin.

9. Karcov G., 1903: Belovežskaja Pušča. Artist. Zaved. A. F. Marksa 1-115. Petersburg.

10. Kleisch J. \& Horst P., 1960: Untersuchungen zur Frage der Farbvererbung beim Rind. Z. f. Tierzücht. Züchtbiol., 74: 106-118.

11. Krasińska M., 1967: Crosses of wisent and domestic cattle. Acta theriol., 12: $67-80$.

12. Krasinska M., 1971: Hybridisation of European bison and domestic cattle. Part VI. Acta theriol., 16: 413-422.

13. Krasińska H., 1979: Progress in breeding European bison and domestic cattle hybrids and casuistics in cases of immobilization and pasteurellosis in hybrids. Acta theriol., 24: 201-210.

14. Lauvergne J. J., 1966: Genetique de la couleur du pelage des Bovines domestiques (Bos taurus Linné). Bibliographia Genetica, 20: 1-68.

15. Małecka G. \& Sumiński E., 1976: Zubronie - nowy rodzaj mięsa. Przegląd hodowlany, 7: 12-13. 
16. Müller F., 1852: Bemerkungen über den Aurochsen. Vierteljahr schr. Wiss. Wet. Kunde., 2: 110-133.

17. Searle A. G., 1968: Comparative genetics of coat colour in mammals. Logos Press: 1-308. New York, London.

18. Shrode R. S. \& Lush J. L., 1947: The genietics of cattle. Advances in Genet., 1: 209-261.

19. Staffe A., 1925: Hybridatavismus bei der Kreuzung rot- und schwarz-bunter Holländer mit braungrauen Alpenvieh und die Verzögerung seines Aufscheinens durch Kastration. Ż. f. Tierzücht u. Züchtbiol., 2: 179-203.

20. Taworski T. \& Woliński Z., 1960: Krzyżówki międzygatunkowe zwierząt uzyskanych w ZOO w Płocku. Przegląd zool., 4: 322-332.

21. Wiethe-Körprich, M., 1952: Einige Betrachtungen über die Farbererbung beim Rind. Z. f. Tierzucht. Zuchtbiol., 60: 205-208.

22. Žuravok I. S., 1935: Gibridy zubrobizona s seroukrainskim i metissimentalskim skotom. Tr. N-i. Inst. Gibrid. i Aklim. Život. Askania Nova, 2: $72-88$. Accepted, September 5, 1980.

\section{APPENDIX I}

Data about colour phenotypes of hybrids between the European bison and domestic cattle. Different patterns of mating was employed.

Colour genotypes:

wisent asas $S S$ er $M$ er $M d d$

bwl asass EE dd

rp asass ererdd

ch $\quad a^{s} a^{s} S S$ erer $e^{r} D$

bwl Xch asss Ss Eer Dd

Explanations and abbreviations:

$w$ - European bison or wisent

bwl - Black and white lowland cattle

$r p$ - Red Polish cattle

ch - Charolaise cattle

$F_{1}$ - hybrids $1 / 2$ wisent $1 / 2$ cattle

$B_{1}$ - $\quad 3 / 4$ wisent $1 / 4$ cattle or $1 / 4$ wisent $3 / 4$ cattle

$\mathrm{B}_{2}$ - $\quad \ldots \quad 1 / 8$ wisent $7 / 8$ cattle

$\mathrm{B}_{3}$ - $\quad 1 / 16$ wisent $15 / 16$ cattle

Colour at the birth was shown only when difference was observed. 

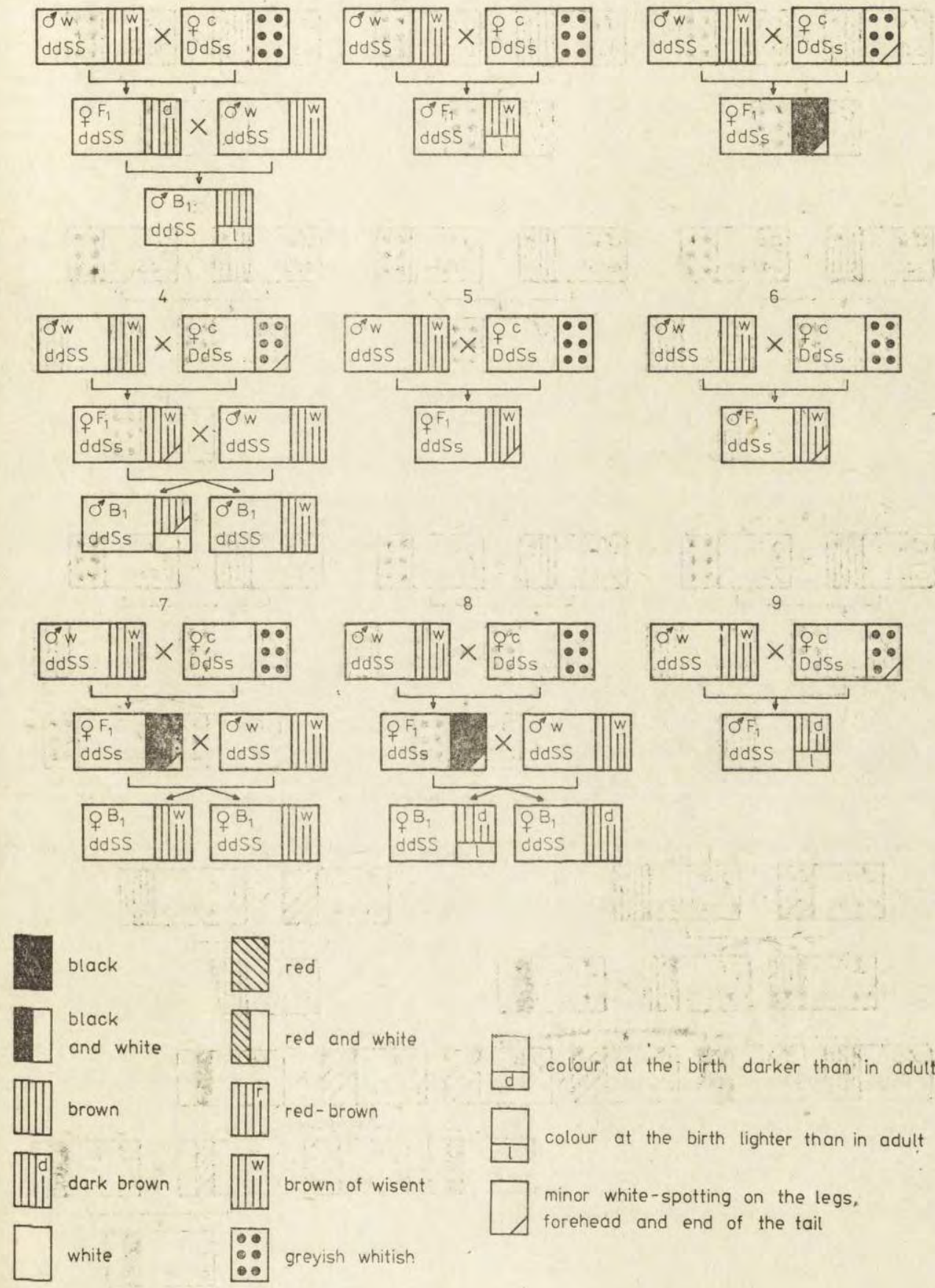

Fig. 1. Colour phenotypes in line I hiybrids $\left(0^{\pi} \sigma^{\pi}\right.$ wisent $\left.\times q q b w l \times c h\right)$. Dominant dilution factor $D$; Self factor $S$, cattle $(b w l \times c h)=C$. 
10

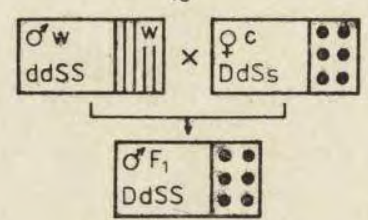

13

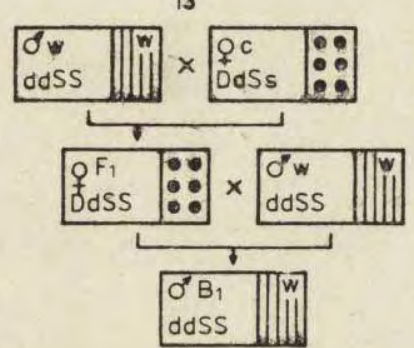

16
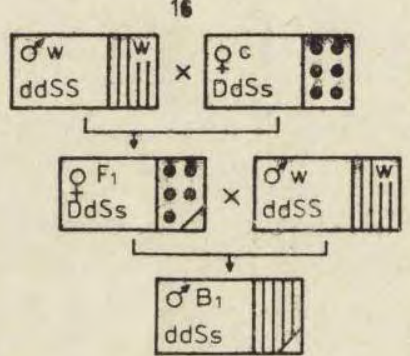

11

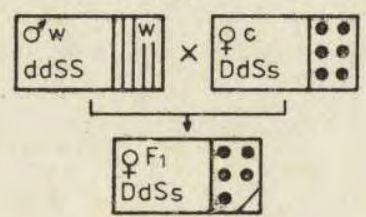

14

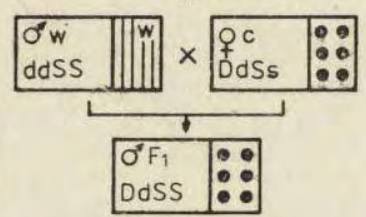

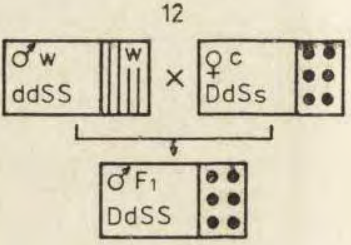

15

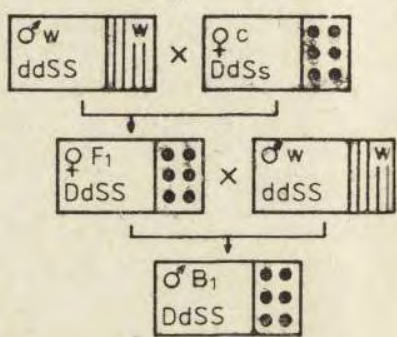

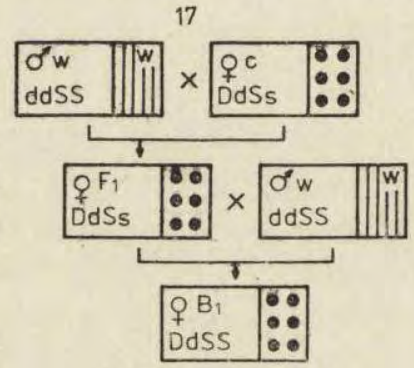

Fis. 1. concluded.

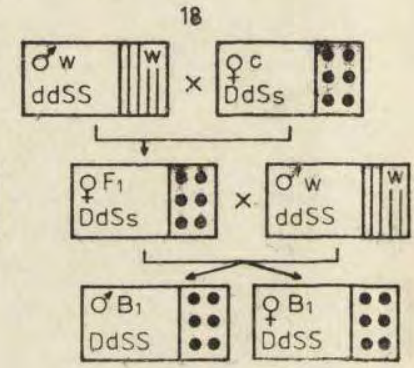

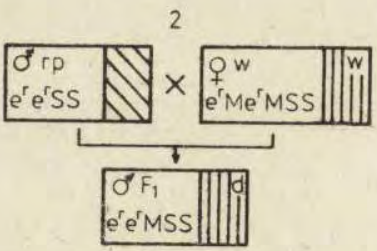
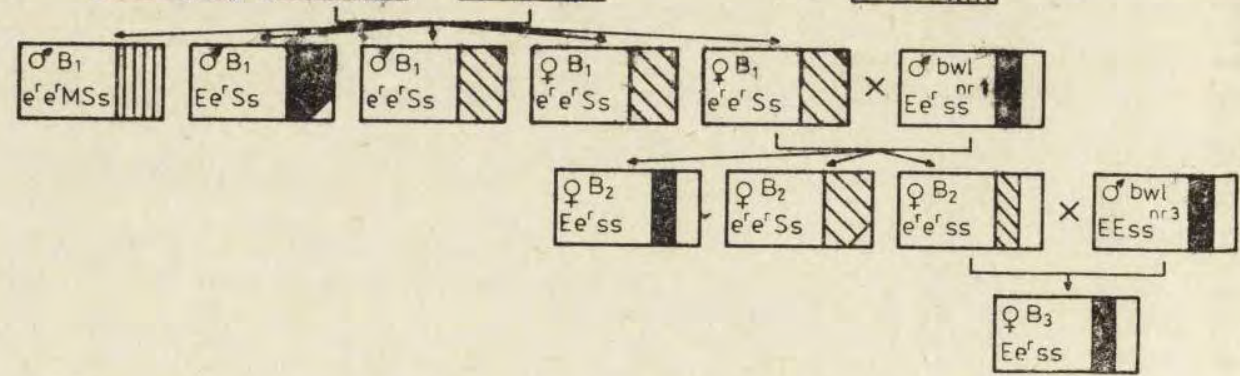

Fig. 2. Colour phenotypes in line II $a \sigma^{*} r p \times q w$.

Extension factor $E$; Dominant modifier bison factor $M$; Self factor $S$. 


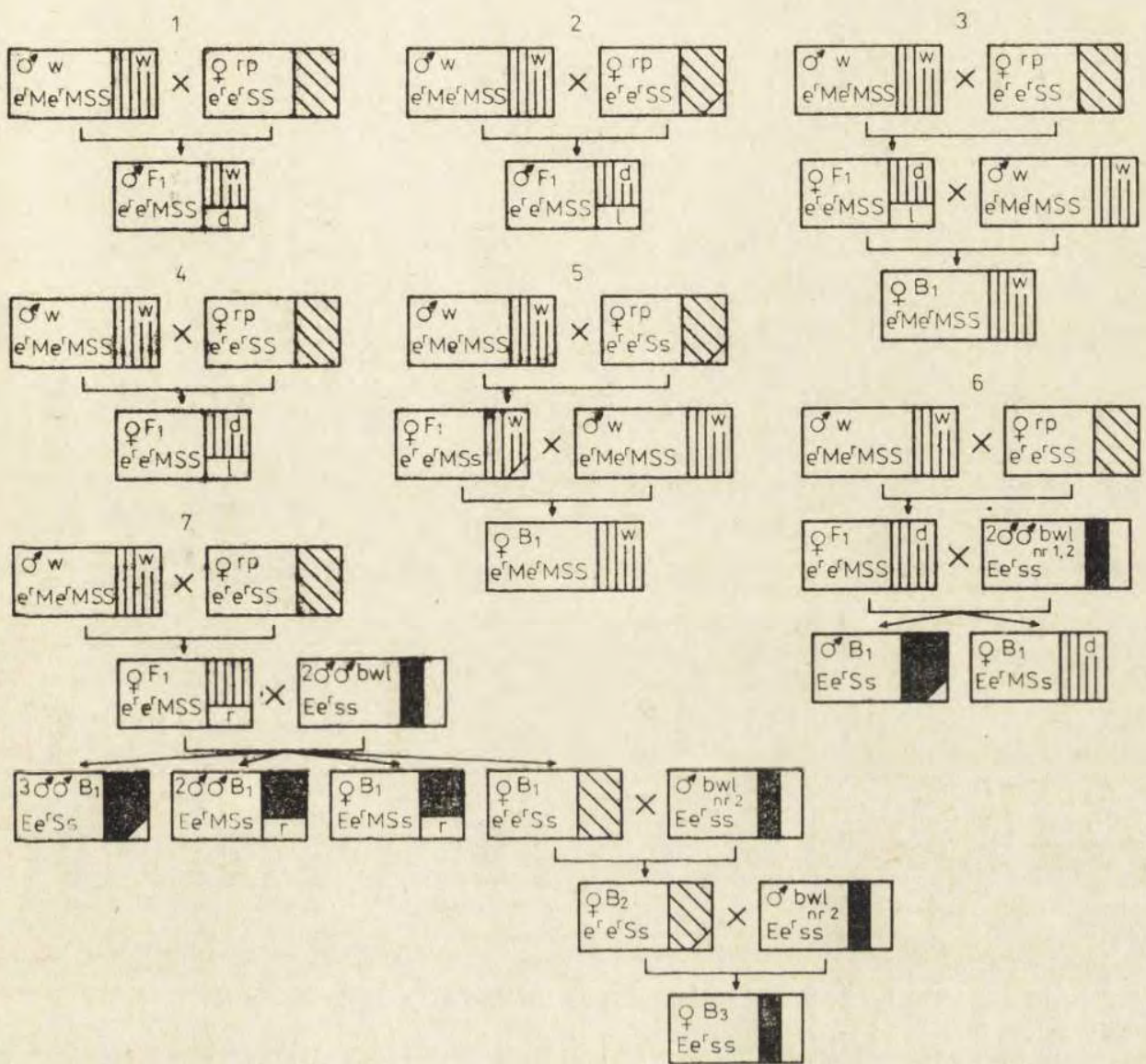

Fig. 3. Colour phenotypes in line $\mathrm{IIb} \sigma \quad w \times \rho r p$.

Extension factor $E$; Dominant modifier bison factor $M$; Self factor $S$. 


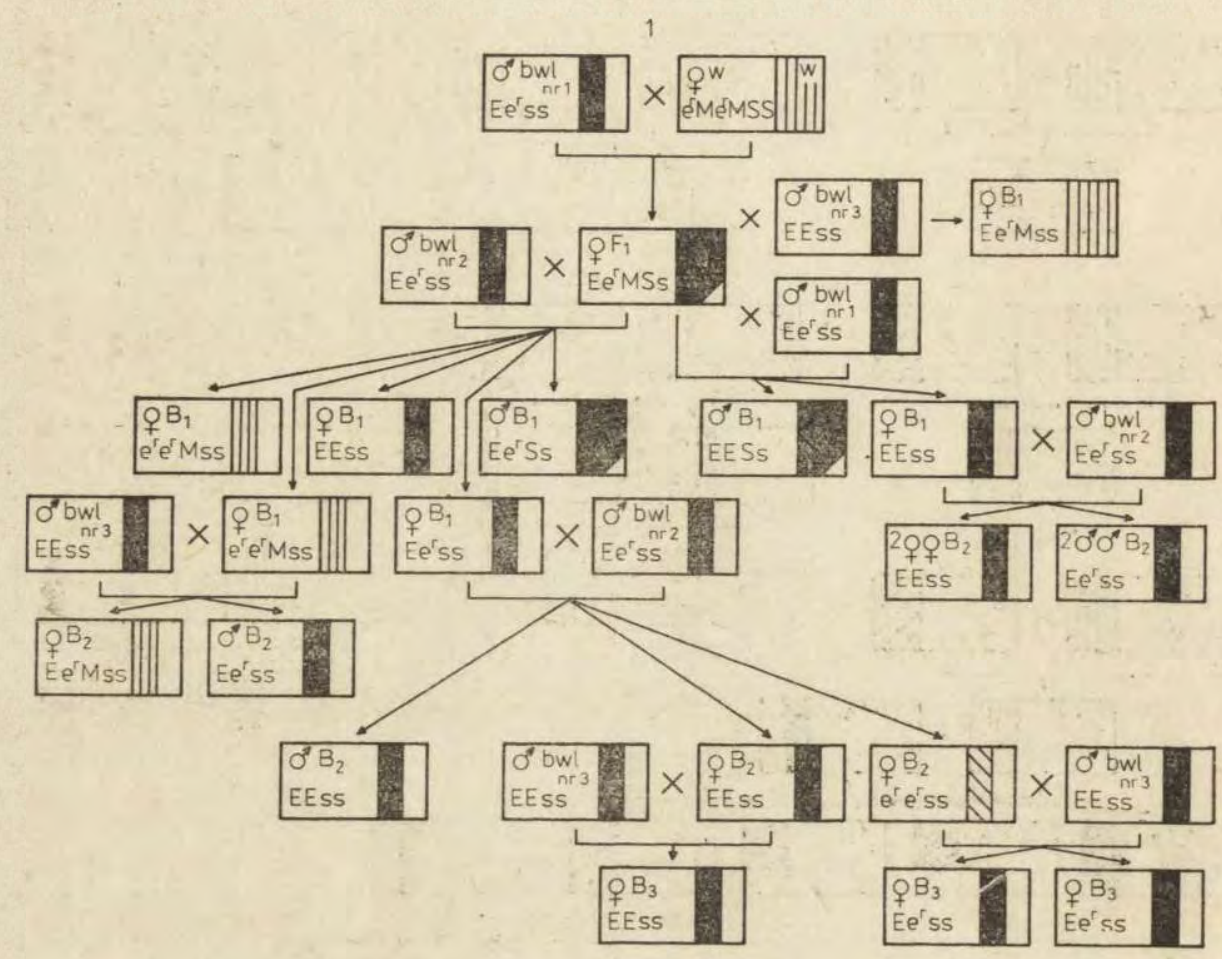

Fig. 4. Colour phenotypes in line IIIa $\sigma^{x}$ bwl $\times$ ㅇ $w$. Extension factor $\bar{E}$; Dominant modifier bison factor $M$; Self factor $S$. 

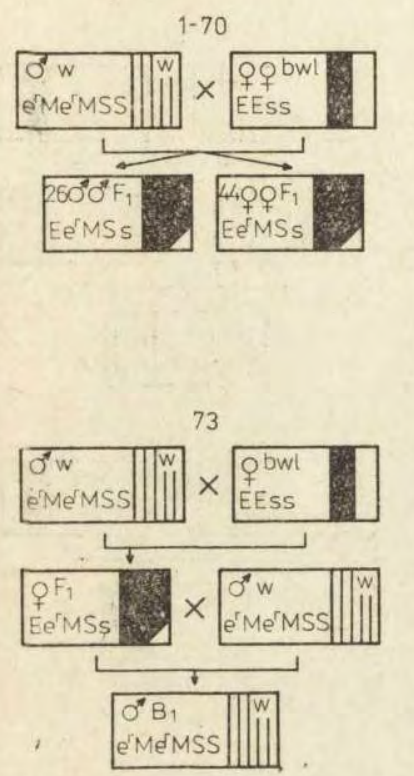

76

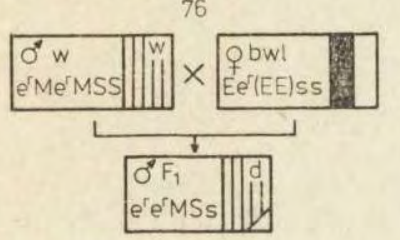

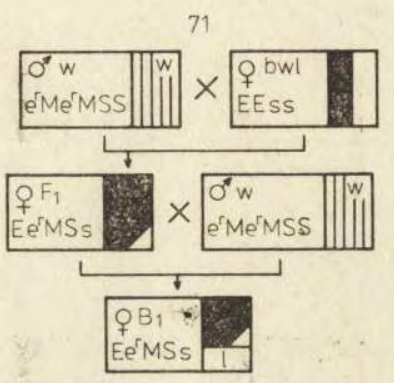

74

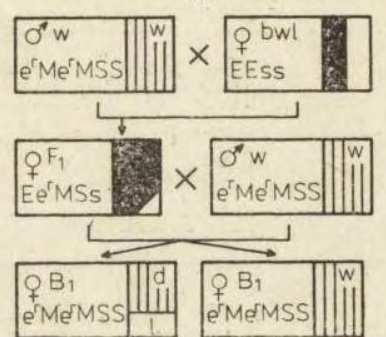

77

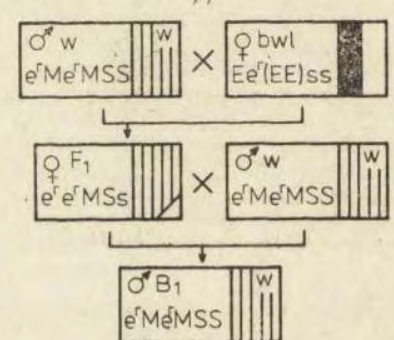

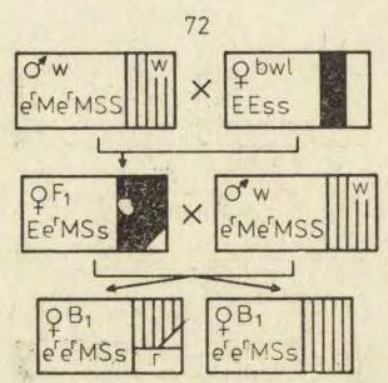

75

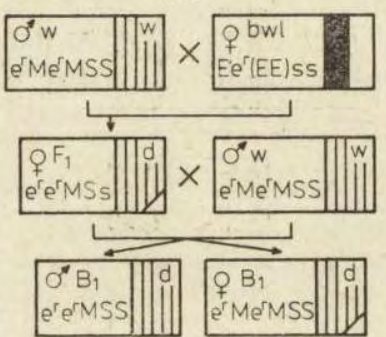

78

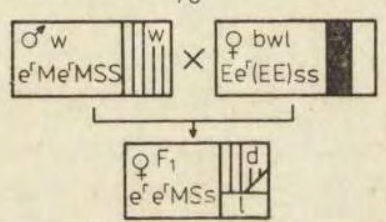

Fig. 5. Colour phenotypes in line IIIb $0^{\pi} w \times q$ b b $w$.

Extension factor $E$; Dominant modifier bison factor $M$; Self factor $S$. 

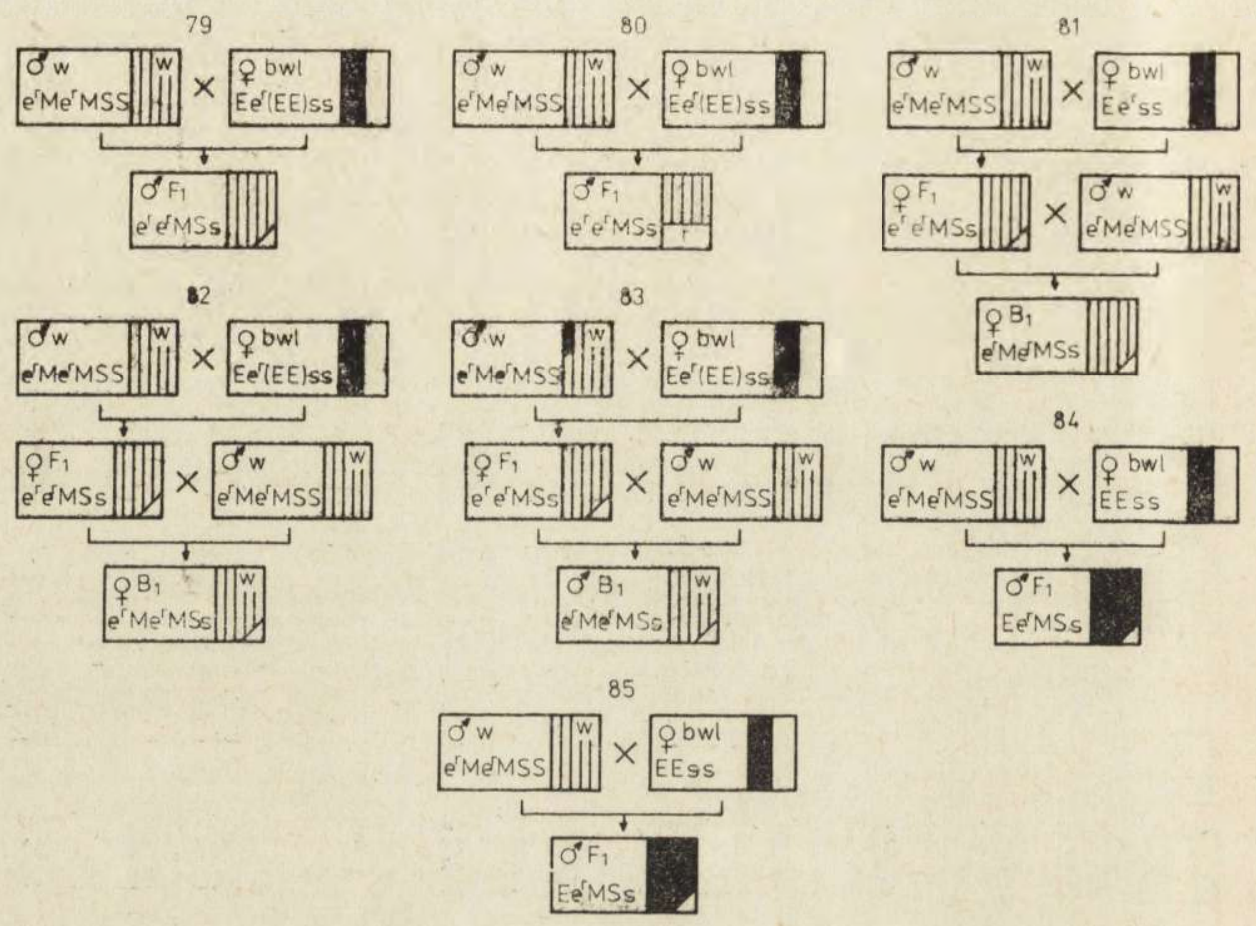

Fig. 5, continued. 


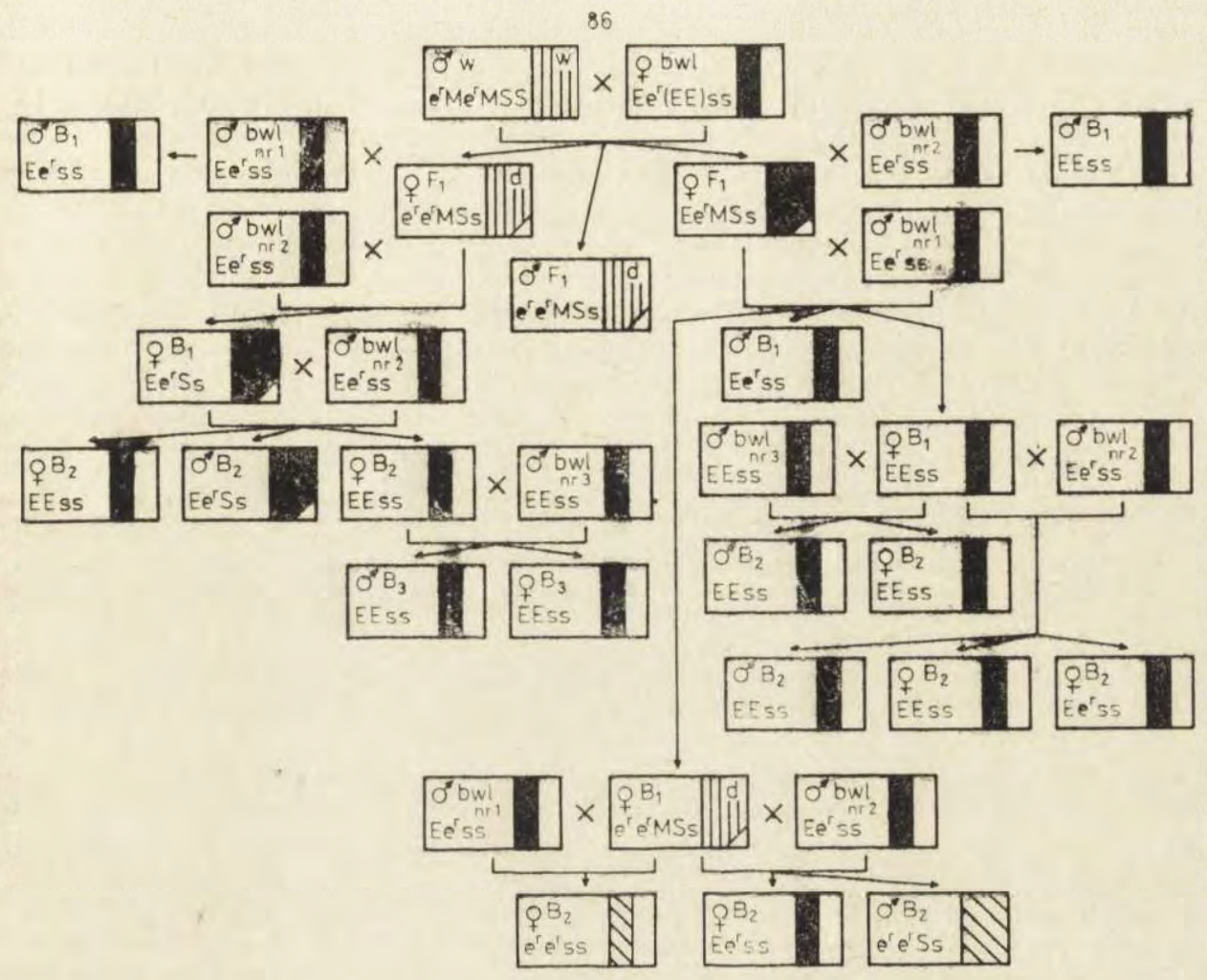

Fig. 5. Concluded.

Małgorzata KRASINSKA i Edward SUMIŃSKI

FENOTYPY UMASZCZENIA HYBRYDOW ŻUBRA I BYDEA DOMOWEGO

Streszezenie

W pracy przeprowadzono analizę dziedziczenia umaszczenia hybrydów żubra z bydlem domowym uzyskanych w Zakładzie Badania Ssaków PAN w Białowieży oraz Państwowym Gospodarstwie Rolnym w Łęknie (Tabela 1). Określono hipotetyczne genotypy umaszczenia form $\mathrm{r}_{\text {odzicielskich } w}$ opa ${ }^{r}{ }$ iu o dane dla europejskich ras bydla w zakresie loci $a, s, e, d$, wykonując jednocześnie pelna dokumentację stosowanych kojarzeń oraz uzyskanych w ich wyniku fenotypów umaszczenia oraz proponowanych genotypów u hybrydów (Tabela 2-4, Appendix I). Założono, że ubarwienie żubra związane jest $z$ obecnością dominującego czynnika modyfikującego, działającego na recesywne uintensywnienie feomelaniny co 
daje w efekcie zciemnienie okrywy żubra do brązu. Prześledzono w różnych kombinacjach i pokoleniach hybrydów występowanie podstawowych maści jak brunatna, czarna, czerwona (Tabela 4). Oddzielnie rozpatrzono cechę jednomaśsistości i białej łaciatości (Tabela 2). Analizowano równieź cechę rozcieńczeria (dilution) umaszczenia $u$ hybrydów posiadających krew bydła rasy charolase (Tabela 3).

Umaszczenie hybrydów było uzależnione od koloru okrywy wlosowej par 10dzicielskich. Przy krzyżowaniu żubrów z bydlem różnych ras otrzymywano hybrydy $F_{1}$ odmiennie umaszczone. Równie ważnym czynnikiem na nie wplywającym był stan homo- czy heterozygotyczności form kojarzonych pod względem par alleli odpowiedzialnych za wystąpienie typowego dla rasy czy gatunku wzorca umaszczenia. Umaszczenie części hybrydów pozwala sądzić, że dwa byki rasy ncb (ojciec i syn) mogły być heterozygotami pod względem genu w locus extension $\left(E e^{r}\right)$.

Uzyskane wyniki pozwalają przypuszczać, że u żubra jak i bydła taki sam czynnik dominujący jest odpowiedzialny za wystąpienie cechy jednomaścistości. Czynnik ten może być allelomorficzny $\mathrm{z}$ genem odpowiedzialnym za wystąpienie recesywnej białej, łaciatości. Obecność odmastek u wszystkich jednolicie umaszczonych hybrydów $F_{1}$ pochodzących po bydle ncb pozwala sądzić, że czynnik bialej laciatości nie jest $\mathrm{w}$ pełni recesywny (Tabela 2 ).

W linii żubr $\times n c b \quad 88 \%$ otrzymanych hybrydów było umaszczone czarno, pozostałe ciemnobrunatne lub czarn'o-brunatne. Wystąpienie brązowego odcienia umaszczenia u części tych hybrydów może być związane $\mathrm{z}$ heterozygotycznością pewnych krów $n c b$ krzyżowanych z żubrem pod względem genu w locus extension (Eer) co powodowałoby, że te hybrydy posiadają genotyp er $e^{r} M$. Innym wytlumaczeniem takiego ubarwienia może być wystąpienie u grupy hybrydów tłumiącego dzialania dominującego czynnika pochodzącego od żubra na gen $w$ locus extension.

$\mathrm{U}$ hybrydów $\mathrm{F}_{1} \mathrm{z}$ linii żubr $\times c p$ występuje ubarwienie $\mathrm{w}$ różnych odcieniach koloru brunatnego będące wynikiem współdziałania genów form rodzicielskich. $z$ których przynajmniej część może zajmować identyczne loci $\left(e^{r} e^{r}\right)$. Analiza ubarwienia $w$ tej grupie hybrydów potwierdza nasze założenia o obecności u żubra czynnika dominującego, odpowiedzialnego za brunatne ubarwienie; potwierdza to również przebieg dziedziczenia fenotypów maści u hybrydów wstecznych $w$ kierunku żubra.

U hybrydów wstecznych maść czarna jest dominująca w stosunku do czerwonej (przy homozygotyczności cech koloru czarnego u foṛmy wyjściowej) Tabela 4. Stwierdzenie dilution umaszczenia u części hybrydów $F_{1}$ żubr $\times$ bydło (ncb $\times$ charolaise) może być dowodem, że cecha ta jest związana $\mathrm{z}$ obecnością przynajmniej jednego czynnika dominującego u rasy charolaise $(D D)$ - Tabela 3.

Autorzy niie mając możliwości wykonania krzyżowań testowych mogli określić tylko hipotetyczne genotypy umaszczenia zarówno form wyjściowych jak i hybrydów. Jednak opierając się na danych z literatury na temat genetyki umaszczenia bydła można było wytłumaczyć powstawanie podstawowych maści u mieszańców, ale nie wystąpienia różnorodnych odcieni. 